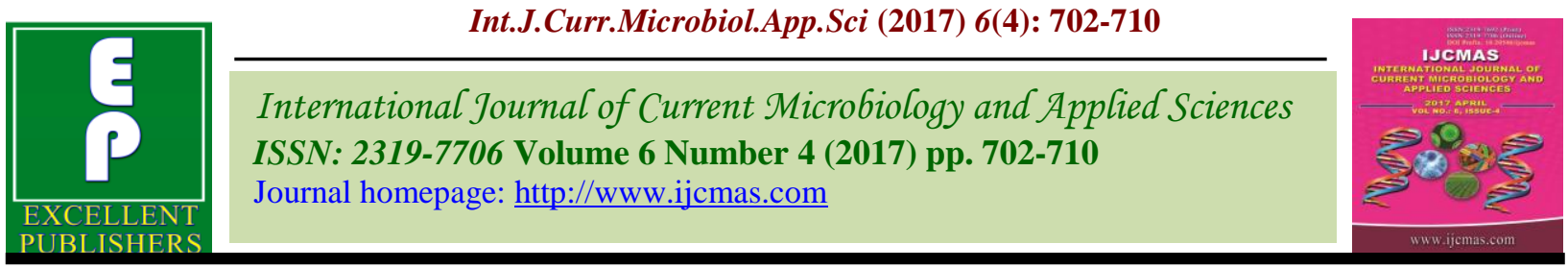

Original Research Article

https://doi.org/10.20546/ijcmas.2017.604.086

\title{
Production of Nutrient Rich Vermicelli with Malted Finger Millet (Ragi) Flour
}

\author{
S.B. Lande*, S. Thorats and A.A. Kulthe \\ Department of Food Science and Technology, MPKV, Rahuri - 413 722, (M.S.) India \\ *Corresponding author
}

A B S T R A C T

\section{Keywords}

Finger millet, malt, vermicelli, sensory properties.

Article Info

Accepted:

06 March 2017

Available Online:

10 April 2017
In present investigation attempts have been made to develop nutrient rich vermicelli by addition of wheat and malted ragi flour in different proportions (90:10 80:20, 70:30, 60:40 and 50:50) for optimization of ratio for production of better quality vermicelli. It was observed that among all the formulations tried, vermicelli sample prepared with 70:30 (wheat: malted ragi flour) combination had similar sensory score as that of control. Higher values of protein, fibre and minerals like calcium, iron and phosphorous than the control sample were reported in vermicelli samples incorporated with $30 \%$ of malted ragi flour. This nutrient rich vermicelli was good source of minerals to the consumers.

\section{Introduction}

Wheat is consumed in various forms by millions of human being in the world. Approximately 85 to $90 \%$ of wheat is consumed as staple food in the form of flat unleavened bread called chapattis, parathas, roti, nan, phulke depending on the method of baking. Wheat is major ingredient in bakery and pasta products due to presence of gluten and its property to form dough and retain gases. It is commercially utilized by large and small scale industries for the production of leavened products such as cake, biscuits, cookies, bread etc. Triticum durum is hard and has high protein content and mainly used for production of semolina, macaroni, and pasta products (Adsule and Kadam, 1986). Wheat is rich in manganese, phosphorus, magnesium, and selenium. It is also a good source of zinc, copper, iron, and potassium. It is rich in vitamin $\mathrm{B}_{6}$, niacin, thiamin, riboflavin, and pantothenic acid. Vitamin $\mathrm{E}$ and $\mathrm{K}$ are also present in smaller, but still significant amounts. The nutritional value of wheat is extremely important as it takes an important place among the few crop species being extensively grown as staple food sources.

Finger millet is commonly known as ragi (Eleusine coracana). It is also known as African millet and Black millet. India is one of the leading countries with respect to production and utilization of ragi. It is extensively grown in Karnataka, Tamil Nadu, Andhra Pradesh, Bihar, Maharashtra and Gujarat. Finger millet needs a fairly high rainfall, but will tolerate poor soil. 
Finger millet is especially valuable as it contains the amino acid methionine, which is lacking in the diets of hundreds of millions of the poor who live on starchy staples such as cassava, plantain, polished rice or maize meal. The finger millet proteins are rich in two of essential amino acids (methionine and tryptophan) and substantial amounts of the essential amino acids, except lysine (Malleshi and Klopfenstein, 1998; Fernandez et al., 2003).

Finger millet is a good source of iron and calcium which especially relevant to populations inhabiting northern Nigeria where the high incidences of prevalence of iron deficiency anemia in pregnant women (VanderJagt et al., 2007) and calcium deficiency rickets in young children (Thacher et al., 2000; Vander Jagt et al., 2001). Finger millet is popular food among diabetic patient in the country. Traditionally finger millet is processed either by malting or fermentation (Rao and Muralikrishna, 2001). Malting of finger millet improves its digestibility, sensory and nutritional quality as well as pronounced effect in the lowering the antinutrients. Malting characteristics of finger millet are superior to other millets and ranks next to barley (Malleshi and Desikachar, 1986; Pawar and Dhanvijay, 2007). There is also overall improvement in the flavour profile of ragi during germination process (Nirmala and Muralikrishna, 2002; Ram et al., 1979; Rao and Belavady, 1978).There are various benefits of malting such as improved availability of vitamin-C, phosphorus and also lysine and tryptophan are synthesized (Dulby and Tsai, 1976).

The malted finger millet had higher amylase activity than sorghum and other millets (Malleshi and Desikachar, 1986; Senappa, 1988). Malleshi and Desikachar, (1986) reported that finger millet has highly agreeable flavour with adequate starch hydrolyzing enzymes.
Vermicelli (little worms) is a type of pasta, round in shape and somewhat thinner than spaghetti. Pasta is the most suitable snack food for satisfying nutritional requirements and safeguarding health (Costantini, 1985). Vermicelli is a popular instant food product which falls under the category of extruded product and is made from wheat flour. It is snack food item rich in proteins and liked by people from all walks of life, irrespective of age. With changing lifestyle greater awareness about health preference for instant food items like vermicelli become very popular and presently it is an item of mass consumption.

\section{Materials and Methods}

Wheat grains of Godawari (NIDW-295) variety and finger millet grains of Phulenachni variety were procured from research stations of MPKV, Rahuri and used for preparation of vermicelli.

\section{Preparation of wheat suji}

Wheat grains were cleaned and subjected to tempering and conditioning treatment. Water was added to wheat sample to increase moisture by $3 \%$ and conditioned overnight. The conditioned grains were milled to obtain suji using laboratory flour mill.

\section{Malted ragi flour}

The malting of ragi was performed by using the process described by Desai et al., (2010). Cleaned grains were washed under water for 5-7 times, soaked for $5 \mathrm{~h}$ in fresh water and then drained to remove excess water. The grains were then tied in a muslin cloth and 5 $\mathrm{Kg}$ weight was kept on it and incubated for 24 $h$ at $27 \pm 3^{\circ} \mathrm{C}$ for germination. The germinated grains were dried in shade for 2 days followed by grinding in Brabender flour mill to make flour. 


\section{Preparation of vermicelli}

The wheat suji and malted finger millet flour was mixed in different levels such as 100:0 $\left(\mathrm{T}_{\mathrm{o}}\right)$, 90:10 (T1), 80:20 ( $\left.\mathrm{T}_{2}\right)$, 70:30 (T3), 60:40 $\left(\mathrm{T}_{4}\right)$, and 50:50 $\left(\mathrm{T}_{5}\right)$. The pre-decided blends of wheat suji and ragi flour were mixed with salt $(2 \%)$ and required amount of water was added to prepare dough of desirable consistency by kneading the dough properly.

\section{Physico-chemical analysis}

The wheat suji, malted ragi flour and vermicelli were subjected to proximate analysis such as moisture, protein, fat, crude fibre, ash, iron, calcium and phosphorous content using standard procedures given by Rangana (1986)

\section{Sensory evaluation}

The vermicelli samples were evaluated for different sensory attributes viz. colour and appearance, texture, flavour, taste and overall acceptability, by panel of 10 semi-trained judges, using a 9 point hedonic scale (Amerine et al., 1965).

\section{Statistical analysis}

The data obtained was analyzed statistically to determine statistical significance of treatments by using Completely Randomized Design (CRD) stated by Panse and Sukhatme (1967).The analysis of variance revealed at significance of $p<0.05$ level, S.E. and C.D. at $5 \%$ level was mentioned wherever required.

\section{Results and Discussion}

\section{Chemical composition of wheat flour}

The moisture content of wheat variety Godawari (NIDW-295) suji was $12.95 \%$ (Table 1). The values for moisture content of wheat flour ranged from 9 to $18 \%$ (Kent Jones and Amos, 1967), 10.3 to $13.8 \%$ (Nannor, 1992) and 10.71 to $13.80 \%$ (Supekar et al., 2005). The value of carbohydrate content obtained in present investigation $(72.22 \%)$ was in agreement with the result obtained by Agarwal (1963).The result indicated that protein content of wheat suji was $12.60 \%$. The mean values for protein content for wheat cultivars reported by earlier researchers were 9.52 to $13.04 \%$ (Austin and Nair, 1964; Aalami et al., 2007). The values for fat content are in good agreement with Khan et al., (1987) who reported crude fat in the range of 0.88 to 2.93 $\%$ in different wheat varieties. The crude fibre content was $0.38 \%$, which is in good agreement with the result obtained by Desai $e t$ al., (2010); Kulkarni et al., (2012) and Singh et al., (2005). The ash content of wheat is chiefly composed of minerals like phosphorus, calcium, iron and potassium. The ash content of wheat suji was found to be 0.95 $\%$. The ash content of whole wheat flour ranged from 0.82 to $2.50 \%$ (Adsule and Kadam, 1986). Aalami et al., (2007) reported that ash content of wheat semolina of different durum varieties varied from 0.79 to $0.86 \%$.

The iron content was $(2.13 \% \mathrm{mg})$ and the values for calcium content $(18.56 \% \mathrm{mg})$ obtained were in agreement with the result recorded by Desai et al., (2010); Kulkarni et al., (2012) and Singh et al., (2005).

The wet and dry gluten content recorded were $39.40 \%$ and $13.80 \%$ respectively. The wet gluten content of Russian durum was in the range of 24.1 to $43.5 \%$ (Mustafar and Guseinov, 1973) and in Indian durum wheat it ranged from 35.3 to $52 \%$ (Rao et al., 1976). The recoveries of wet and dry gluten ranged from 22.2 to $39.2 \%$ and 8 to $12.2 \%$ respectively (Adsule $e t$ al., 1985). Pharande $e t$ al., (1988 b) reported the values of wet and 
dry gluten as $35.2 \%$ and $11.9 \%$ for $\mathrm{N}-8223$, $30.0 \%$ and $10.3 \%$ for NI-5439 and $33.4 \%$ and $11.0 \%$ for N-59 cultivars of wheat respectively. Aalami et al., (2007) reported that wet gluten content of wheat semolina of different durum varieties varied from 25.2 to $34.4 \%$. The sedimentation value is based on the fact that gluten protein absorbs water and swells completely when treated with lactic acid. The sedimentation value of NIDW-295 was found to be $31 \mathrm{ml}$. Austin and Nair (1964) reported that the sedimentation values for Indian and foreign wheat cultivars in the range of 52 to $63 \mathrm{ml}$ and 54 to $63 \mathrm{ml}$ respectively. The sedimentation values reported were 15.8 and $14.5 \mathrm{ml}$ for DWL5023 and PBW-34 cultivars respectively (Singh and Paliwal, 1986). However, Ram et al., (2001) reported the sedimentation values of wheat, which ranged from 35 to $37 \mathrm{ml}$ for 13 wheat lines from Durgapur and 29 to $58 \mathrm{ml}$ for 13 wheat lines from Pantnagar. Pinckney et al., (1957) classified wheat flours on the basis of sedimentation value into four groups as $1^{\text {st }}$ (60 and over), $2^{\text {nd }}$ (40 to 59$), 3^{\text {rd }}$ (20 to 39 ) and $4^{\text {th }}$ (less than 20). They reported that $3^{\text {rd }}$ group wheat flour was suitable for the production of "all purpose" flour.

\section{Chemical composition of finger millet flour}

It was found that plain and malted finger millet variety phulenachani flours contained 13.57 and $12.45 \mathrm{mg} / 100 \mathrm{~g}$ irons respectively (Table 2). The iron content of finger millet ranged from 3.3 to $14.8 \mathrm{mg} / 100 \mathrm{~g}$ (Babu et al., 1987). Singh and Shrivastav (2006) reported that the iron content of 16 finger millet varieties ranged from 3.61 to $5.42 \mathrm{mg} / 100 \mathrm{~g}$. The calcium content was 335.40 and 397.67 $\mathrm{mg} / 100 \mathrm{~g}$ for plain and malted finger millet flours respectively. The finger millet contained calcium in the range of 162 to 487 $\mathrm{mg} / 100 \mathrm{~g}$ with mean $320.8 \mathrm{mg} / 100 \mathrm{~g}$ (Vadivoo et al., 1998), $329 \mathrm{mg} / 100 \mathrm{~g}$ in white variety and $296 \mathrm{mg} / 100 \mathrm{~g}$ in brown (Seetharam, 2001). Bhatt et al., (2003) reported 344 $\mathrm{mg} / 100 \mathrm{~g}$ calcium content in finger millet flour. The phosphorus content was 238.33 and $254.50 \mathrm{mg} / 100 \mathrm{~g}$ for plain and malted finger millet flour respectively.

Table.1 Proximate composition of wheat flour

\begin{tabular}{|l|c|}
\hline \multicolumn{1}{|c|}{ Proximate composition } & $\begin{array}{c}\text { Wheat } \\
\text { (NIDW-295) }\end{array}$ \\
\hline Moisture (\%) & 12.95 \\
\hline Carbohydrate (\%) & 72.22 \\
\hline Protein (\%) & 12.60 \\
\hline Fat (\%) & 0.90 \\
\hline Crude fibre (\%) & 0.38 \\
\hline Ash (\%) & 0.95 \\
\hline Iron (m/100 g) & 2.13 \\
\hline Calcium $(\mathrm{mg} / 100 \mathrm{~g})$ & 18.56 \\
\hline Phosphorus(mg/100 g) & 107.67 \\
\hline Wet gluten $(\%)$ & 39.40 \\
\hline Dry gluten $(\%)$ & 13.80 \\
\hline Sedimentation value (ml) & 31.00 \\
\hline
\end{tabular}


Table.2 Proximate composition of plain and malted finger millet flour

\begin{tabular}{|l|c|c|}
\hline \multicolumn{1}{|c|}{ Proximate composition } & $\begin{array}{c}\text { Ragi } \\
\text { (PhuleNachani) }\end{array}$ & $\begin{array}{c}\text { Malted Ragi } \\
\text { (PhuleNachani) }\end{array}$ \\
\hline Moisture (\%) & 10.50 & 10.56 \\
\hline Carbohydrate (\%) & 77.23 & 78.93 \\
\hline Protein (\%) & 6.33 & 6.42 \\
\hline Fat (\%) & 1.08 & 1.14 \\
\hline Crude fibre (\%) & 3.15 & 3.36 \\
\hline Ash $(\%)$ & 1.91 & 1.96 \\
\hline Iron $(\mathrm{mg} / 100 \mathrm{~g})$ & 13.57 & 12.45 \\
\hline Calcium $(\mathrm{mg} / 100 \mathrm{~g})$ & 335.40 & 397.67 \\
\hline Phosphorus(mg/100 g) & 238.33 & 254.50 \\
\hline
\end{tabular}

Table.3 Nutritional composition of vermicelli prepared with blends of wheat and malted finger millet flour

\begin{tabular}{|c|c|c|c|c|c|c|c|c|}
\hline Treatments & $\begin{array}{c}\text { Carboh } \\
\text { ydrate } \\
(\boldsymbol{\%})\end{array}$ & $\begin{array}{c}\text { Protein } \\
(\boldsymbol{\%})\end{array}$ & $\begin{array}{c}\text { Fat } \\
(\boldsymbol{\%})\end{array}$ & $\begin{array}{c}\text { Ash } \\
(\boldsymbol{\%})\end{array}$ & $\begin{array}{c}\text { Crude } \\
\text { fibre } \\
(\boldsymbol{\%})\end{array}$ & $\begin{array}{c}\text { Iron } \\
(\mathbf{m g} / \mathbf{1 0 0 g})\end{array}$ & $\begin{array}{c}\text { Calcium } \\
(\mathbf{m g} / \mathbf{1 0 0 g})\end{array}$ & $\begin{array}{c}\text { Phosphorus } \\
(\mathbf{m g} / \mathbf{1 0 0 g})\end{array}$ \\
\hline $\mathrm{T}_{0}$ & 76.93 & 11.97 & 0.86 & 2.80 & 0.36 & 1.88 & 15.02 & 104.18 \\
\hline $\mathrm{T}_{1}$ & 77.32 & 11.35 & 0.88 & 2.90 & 0.66 & 2.91 & 53.92 & 118.85 \\
\hline $\mathrm{T}_{2}$ & 77.74 & 10.73 & 0.91 & 3.00 & 0.95 & 3.74 & 91.83 & 133.56 \\
\hline $\mathrm{T}_{3}$ & 78.19 & 10.12 & 0.93 & 3.11 & 1.24 & 4.95 & 129.75 & 148.21 \\
\hline $\mathrm{T}_{4}$ & 78.64 & 9.50 & 0.96 & 3.20 & 1.56 & 6.00 & 166.78 & 162.90 \\
\hline $\mathrm{T}_{5}$ & 79.08 & 8.88 & 0.98 & 3.31 & 1.85 & 7.03 & 204.57 & 177.58 \\
\hline Mean & $\mathbf{7 7 . 9 8}$ & $\mathbf{1 0 . 4 3}$ & $\mathbf{0 . 9 2}$ & $\mathbf{3 . 0 5}$ & $\mathbf{1 . 1 0}$ & $\mathbf{4 . 4 2}$ & $\mathbf{1 1 0 . 3 1}$ & $\mathbf{1 4 0 . 8 8}$ \\
\hline SE \pm & $\mathbf{0 . 0 5 8}$ & $\mathbf{0 . 0 6 3}$ & $\mathbf{0 . 0 2 3}$ & $\mathbf{0 . 0 1 8}$ & $\mathbf{0 . 0 2 7}$ & $\mathbf{0 . 0 3 1}$ & $\mathbf{0 . 0 4 7}$ & $\mathbf{0 . 0 3 9}$ \\
\hline CD at 5 \% & $\mathbf{0 . 1 8 1}$ & $\mathbf{0 . 1 9 5}$ & $\mathbf{0 . 0 7 1}$ & $\mathbf{0 . 0 5 7}$ & $\mathbf{0 . 0 8 3}$ & $\mathbf{0 . 0 9 7}$ & $\mathbf{0 . 1 4 7}$ & $\mathbf{0 . 1 2 0}$ \\
\hline
\end{tabular}

Table.4 Sensory evaluation of vermicelli prepared with different blends of wheat and malted finger millet flour

\begin{tabular}{|c|c|c|c|c|c|}
\hline Treatment & $\begin{array}{c}\text { Colour and } \\
\text { appearance }\end{array}$ & Texture & Flavour & Taste & $\begin{array}{c}\text { Overall } \\
\text { acceptability }\end{array}$ \\
\hline $\mathrm{T}_{0}$ & 8.75 & 8.00 & 8.00 & 8.75 & 8.50 \\
\hline $\mathrm{T}_{1}$ & 8.00 & 7.75 & 7.50 & 8.00 & 8.00 \\
\hline $\mathrm{T}_{2}$ & 7.75 & 7.50 & 7.25 & 7.75 & 7.63 \\
\hline $\mathrm{T}_{3}$ & 7.50 & 7.25 & 7.00 & 7.50 & 7.38 \\
\hline $\mathrm{T}_{4}$ & 7.00 & 7.00 & 6.75 & 7.25 & 7.13 \\
\hline $\mathrm{T}_{5}$ & 6.75 & 6.75 & 6.50 & 6.75 & 6.88 \\
\hline Mean & $\mathbf{7 . 6 3}$ & $\mathbf{7 . 3 8}$ & $\mathbf{7 . 1 7}$ & $\mathbf{7 . 6 7}$ & $\mathbf{7 . 5 8}$ \\
\hline SE \pm & $\mathbf{0 . 1 7 6}$ & $\mathbf{0 . 2 0 4}$ & $\mathbf{0 . 1 7 7}$ & $\mathbf{0 . 1 4 4}$ & $\mathbf{0 . 1 1 9}$ \\
\hline CD at 5 \% & $\mathbf{0 . 5 5 4}$ & $\mathbf{0 . 6 2 8}$ & $\mathbf{0 . 5 4 4}$ & $\mathbf{0 . 4 4 4}$ & $\mathbf{0 . 3 6 6}$ \\
\hline
\end{tabular}




\section{Nutritional composition of Vermicelli}

It was observed that with increased amount of processed finger millet flour upto 50 per cent there was increase in carbohydrate content of vermicelli from 76.93 to $79.08 \%$ (Table 3).It was observed that there was positive relation of carbohydrate content and inverse relation of protein content and levels of malted processed finger millet flour. The decrease in protein content from 11.97 to $8.88 \%$ in vermicelli was observed with increase in ragiflour. The decrease in protein content with vermicelli might be due to the lower protein content in malted finger millet flour compared to wheat. The mean increase in fat content from 0.86 to $0.98 \%$ was observed with increase in ragi flour in wheat flour from 0 to $50 \%$ and also ash content from 2.80 to $3.31 \%$. It was observed that there was positive relation of ash content and levels of malted finger millet flour. Shukla and Srivastav (2014) recorded carbohydrates (78.54\%), proteins $(6.7 \%)$, crude fat (1.15 $\%)$ and crude fibres $(1.28 \%)$ in noodles incorporated with 50 per cent finger millet flour. They reported increase in carbohydrates, fats and fibres while decrease in protein content of noodles with increased level of finger millet up to 50 per cent. The protein content gradually decreased from 16.3 to $11.3 \%$ while fibre content marginally increased from 17.4 to $19.4 \%$ with no significant difference in fat content for control and ragi incorporated vermicelli.

It was observed that with increased amount of malted finger millet flour up to 50 per cent resulted in increased iron content from 1.88 to $7.03 \mathrm{mg} / 100 \mathrm{~g}$ in vermicelli. The mean increase in the calcium content was observed from 15.02 to $204.57 \mathrm{mg} / 100 \mathrm{~g}$ with increased level of ragi flour with wheat flour. The increase in the phosphorus content was observed from 104.18 to $177.58 \mathrm{mg} / 100 \mathrm{~g}$ with increased levels of malted finger millet flour. It was observed that there was direct relation of phosphorus content and levels of malted finger millet flour. Shukla and Srivastav (2014) recorded increased ash content $(1.4 \%)$, iron $(5.5 \mathrm{mg} / 100 \mathrm{~g})$ and calcium $(88.3 \mathrm{mg} / 100 \mathrm{~g})$ in noodles incorporated with 50 per cent finger millet flour. The ash content gradually increased from 1.06 to 1.46 per cent while fibre content marginally increased from 2.4 to $3.9 \mathrm{mg} / 100 \mathrm{~g}$ for control and ragi incorporated vermicelli.

Shukla et al., (1986) reported that total carbohydrate ranged from 73.7 to $83.1 \%$ and 4.6 to $5.7 \%$ protein in malted finger millet. Rao (1994) reported 8.2 and $11.3 \%$ protein content in brown and white varieties of malted finger millet respectively. Hemanalini et al., (1980) have reported that malted finger millet flour resulted in 32, 26 and 33\% losses in calcium, phosphorous and iron respectively. Such losses have been observed, due to removal of seed coat of finger millet grains. Sprouted finger millet contained $323.85 \mathrm{mg}$ calcium, $230 \mathrm{mg}$ phosphorous and $5 \mathrm{mg}$ iron. Ionisable iron (27.1 and 55\%) and soluble zinc (81 and 25\%) content increased significantly after malting, in brown and white finger millet (Rao, 1994). Mamiro et al., (2001) reported that germination of finger millet for $48 \mathrm{~h}$ significantly increased the in vitro extractability of calcium, iron and zinc.

\section{Sensory evaluation of vermicelli}

The increased amount of malted finger millet flour up to 50 per cent, there was decrease in colour and appearance, texture, flavour, taste and overall acceptability which ranged from 8.75 to $6.75,8.00$ to $6.75,8.00$ to $6.50,8.75$ to 6.75 and 8.50 to 6.88 respectively (Table 4).

The vermicelli samples of $\left(\mathrm{T}_{3}\right.$ treatment 70:30) were more acceptable than other treatments and were comparable to control. Kulkarni et al., (2012) reported that noodles prepared with 30 per cent finger millet flour 
and $70 \%$ wheat flour combination had same sensory score as that of control and also higher values of protein, fibre and minerals than the control sample. Eneche (1999) observed that biscuits prepared using 65 per cent millet flour and 35 per cent pigeon pea meal blend were highly acceptable in sense of flavour, texture and general acceptability. Sahoo (2010) reported similar sensory score of cake samples prepared with wheat (malted) and finger millet flour (50:50).

In conclusion the use of finger millet in vermicelli improved the nutritional status of vermicelli with respect to crude fibre, iron and calcium content by four, three and six fold respectively by addition of ragi flour upto $30 \%$ in wheat flour. This vermicelli was also more acceptable on the basis of sensory parameters.

\section{References}

Adsule, R.N. and Kadam, S.S. 1986. Quality of wheat In: Quality of Wheat and Wheat Products (Salunkhe, D. K., Kadam, S. S. and Austin, A., eds.), Metropolitan Press, New Delhi, 1-6.

Adsule, R.N., Lawande, K.M., Dhorte, V.A. and Kadam, S.S. 1985. Quality characteristics of some wheat varieties. J. Mah. Agric. Univ., 10: 107-108.

Agarwal, N.S. 1963. Wheat characteristic in relation to utilization. Bull. Grain Technol., 1: 16-23.

Alami, M., Leelavathi, K. and Prasada Rao, U.J.S. 2007. Spaghetti making potential of Indian durum wheat varieties in relation to their protein, yellow pigment and enzyme contents. Food Chem., 100: 1243-1248.

Amerine, M.A., Pangborn, R.M. and Rossler, E.A. 1965. Principle of Sensory Evaluation of Food. Academic Press, London. pp: 350-376.

Austin, A. and Nair, R. 1964. Comparative study of sedimentation value and protein content of some improved Indian and foreign wheat. Indian $J$. Agric. Sci., 24: 15-17.

Babu, B.V., Ramana, T., and Radhakrishna, T.M. 1987. Chemical composition and protein in hybrid varieties of finger millet. Indian J. Agric. Sci., 57(7): 520522.

Bhatt, A., Singh V., Shrotia, P.K., and Baskheti, D.C. 2003. Coarse grains of Uttaranchal: Ensuring sustainable food and nutritional security. Indian Farmer's Digest, pp: 34-38.

Costantini, A.M. 1985. Nutritional and health significance of pasta in modern dietary patterns. In Mercierch \& Cantarelli, C. (Eds.), Pasta and Extrusion Cooked Foods. London:

Elsevier Applied Science Publisher. 1986. pp: 1-9.

Desai, A.D., Kulkarni, S.S., Sahu, A.K., Ranveer, R.C. and Dandge, P.B. 2010. Effect of supplementation of malted finger millet flour on the nutritional and sensorial characteristics of cake. $A d v . J$. Food Sci. Technol., 2(1): 67-71.

Dulby, A. and Tsai, C. 1976. Lysine and tryptophan increases during germination of cereal grains. Cereal Chem., 53: 222224.

Eneche, E.H. 1999. Biscuit making potential of millet/pigeonpea flour blends. Plant Foods for Human Nutri., 54: 21-27.

Hemanalini, G., Umapathy, K.P., Rao, J.R, Saraswathi, G. 1980. Nutritional evaluation of sprouted ragi. Nutr. Rep. Int., 22(2): 271-277.

Fernandez, D.R., Vanderjagt, D.J., Millson, M., Huang, Y.S., Chung, L.T., Pastuszym, A. and Glew, R.H. 2003. Fatty acid, amino acid and trace mineral composition of Eleusinecoracana (Pwana) Seeds from northern Nigeria. Plant Foods for Human Nutr., 58: 1-10. Kent Jones, D.W. and Amos, A.J. 1967. 
Composition of wheat and product milling. In: Modern Cereal Chemistry. Sixth Edition, Food Trade Press Limited, London, pp: 1-38.

Khan, M.A., Rashid, J. and EI-Haramein, F.J. 1987. Technological values of some Pakistani wheat varieties. Pak. J. Agric. Res., 8(2): 121-124.

Kulkarni, S.S., Desai, A.D., Ranveer, R. and Sahoo, A.K. 2012. Development of nutrient rich noodles by supplementation with malted ragi flour. Int. Food Res. J., 19(1): 309-313.

Malleshi, N.G. and Desikachar, H.S.R. 1986. Influence of malting conditions on quality of finger millet. J. Instant Brewing, 92: 81-83.

Malleshi, N.G. and Klopfenstein, C.F. 1998. Nutrient composition and amino acid content of malted sorghum; pearl millet and finger millet and their milling fractions. J. Food Sci. Technol., 35: 247-249.

Mamiro, P.R.S., Vancamp, J., Mwiky, S.M. and Huyghrbaert, A. 2001. In vitro extractability of calcium, iron and zinc in finger millet and kidney beans during processing. J. Food Sci., 66(9): 12711275 .

Mustafar, I.D. and Guseinov, A.G. 1973. Vestnik Sel'sknkhozyaistvennoi, Nauki, Moscow, USSR, pp: 12-16.

Nanoor, B.S. 1992. Studies on nutritional quality of some wheat cultivars. A M. Sc.(Agri.) Thesis, Mahatma PhuleKrishi Vidyapeeth, Rahuri, Distt. Ahmednagar, Maharashtra, India.

Nirmala, M. and Murlikrishna, G. 2002. Changes in starch during malting of finger millet and its in vitro digestibility studies using purified ragi amylases. $J$. Eur. Food Res. Technol., 215: 327-333.

Panse, V.S. and Sukhatme, P.V. 1967. Statistical Methods for Agricultural Workers, ICAR, New Delhi, pp: 70-72.
Pawar, P.A. and Dhanvijay, V.P. 2007. Weaning Foods: An overview. Bev. Food World, 34: 27-33.

Pharande, A.L., Dhotre, V.A., Lawande, K.M. and Adsule, R.N. 1988b. Evaluation of quality of some promising wheat varieties. J. Mah. Agric. Univ., 13: 133134.

Pinckney, A.J., Greenaway, W.T. and Zeleny, L. 1957. Further development in the sedimentation test of wheat quality. Cereal Chem., 34: 16-25.

Ram, S., Misra, B.K. and Nagarajan, S. 2001. Biscuit making quality of advance lines of wheat in India. J. Food Sci. Technol., 38: 476-479.

Ranganna, S. 1986. Handbook of Analysis and Quality Control for Fruits and Vegetable Product.2nd Ed. Tata McGrahill Publications, pp: 123-127.

Rao, P.U. 1994. Evaluation of protein quality of brown and white ragi (Eleusinecoracana) before and after malting. Food Chem., 51: 433-436.

Rao, P.U. and Belavady, B. 1978. Oligosaccharides in pulses: varietal difference and effects of cooking andgermination. J. Agric. Food Chem., 26: $316-319$.

Rao, S.M.V.S.S.T. and G. Muralikrishna. 2001. Nonstarch polysaccharides and bound phenolic acids from native and malted finger millet (Ragi, Eleusinecoracana, Indaf-15). Food Chem., 72: 187-192.

Rao, P.H., Rahim, A., Prabhavati, C. and Shurpalekar, S.R. 1976. Physicochemical, rheological and milling characteristics of Indian durum wheat. J. Food Sci. Technol., 13: 317-322.

Sahoo, A.K. 2010. Effect of supplementation of malted finger millet flour on the nutritional and sensorial quality characteristic of cake. Adv. J. Food Sci. Technol., 2: 67-71. 
Seetharam, A. 2001. Annual report 2000-01. All India Co-ordinated Small Millet Improvement Project, Bangalore, pp: 128.

Senappa, M. 1988. Sorghum and millets in east Africa with reference to their use in weaning foods In: Proceedings of workshop, Nairobi, Kenya, 12-16 October, 1987. Improving young child feeding in eastern and southern Africa: household level food technology. Alnwick D, Moses S, Schmidt O G eds. Ottawa, International Development Research Centre. pp: 39-54.

Shukla, S.S., Gupta, O.P., Suarkar, N.J., Tomar, A.K., Sharma, Y.K. 1986. Malting quality of ragi varietiesnutrient and mineral composition of their malts. Indian J. Nutr. Diet., 28(8): 223-227.

Shukala, K. and Srivastava, S. 2014. Evaluation of finger millet incorporated noodles for nutritive value and glycemic index. J. Food Sci. Technol., 51(3): 527-534.

Singh, G. and Paliwal, S.C. 1986. Physicochemical, milling and bread making quality of two varieties of durum wheat. Bull. Grain Technol., 24: 73-76.

Singh, P. and Srivastava, S. 2006. Nutritional composition of sixteen new varieties of finger millet. J. Community Mobilization Sustainable Dev., 1(2): 8184.

Singh, P., Singh, G., Srivastava, S. and
Agarwal, P. 2005. Physiochemical characteristics of wheat and finger millet blends. J. Food Sci. Technol., 42: 340-343.

Supekar, D.T., Patil, S.R., and Munjal, S.V. 2005. Comparative study of some important aestivum, durum and dicoccum wheat cultivars for grain quality, flour quality and suitability for chapatti making characteristics. J. Food Sci. Technol., 42(6): 488-492.

Thacher, T.D., Fischer, P.R., Pettifor, J.M., Lawson, J.O., Isichel, C.O. and Chan, G.M. 2000. Case-control study of factors associated with nutritional rickets in Nigerian children. $J$. Pediatrics, 137: 367-373.

Vadivoo, A.S., Joseph, R, and Garesan, N.M. 1998. Genetic variability and calcium content in finger millet (Eluesinacoracana L. gaertin) in relation to grain colour. Plant Foods Hum. Nutr., 52(4): 353-364.

Vanderjagt, D.J., Brock, H.S., Melah, G.S., El-Nafaty, A.U., Crossy, M.J. and Glew, R.H. 2007. Nutritional factors associated with anemia in pregnant women in northern Nigeria. J. Health, Population and Nutr., 25: 75-81.

Vanderjagt, D.J., Morales, M., Thacher, T.D., Diaz, M. and Glew, R.H. 2001.Bioelectrical impedance analysis of the body composition of Nigerian children with calcium deficiency rickets. J. Trop. Pediatrics, 47: 92-97.

\section{How to cite this article:}

Lande, S.B., S. Thorats and Kulthe, A.A. 2017. Production of Nutrient Rich Vermicelli with Malted Finger Millet (Ragi) Flour. Int.J.Curr.Microbiol.App.Sci. 6(4): 702-710. doi: https://doi.org/10.20546/ijcmas.2017.604.086 